\title{
EN VÄRLD AV UNDER
}

\section{Gunnar Broberg}

En gång visste människan att förundras. Hon häpnade och beundrade skapelsen, hon fann dolda gudomliga budskap i naturen, som kompletterade den bibliska uppenbarelsen. Naturen var måhända fallen men vittnade likafullt om en välvillig skapargud. En del av detta exponerades i de gamla kuriosakabinetten som sköttes av dem som visade "cura", eller brydde sig om skapelsens mångfald. Att vara "kuriös", ett ord som tappat $i$ status, innebar att vara både dygdig och lärd. Det forrsta svenska vetenskapliga samfundet, grundat pestens ar 1710 i Uppsala, kallades Collegium curiosorum.

Kuriosakabinettens ursprung går åt olika håll. I kyrkorna visades under medeltiden "jätteben" (egentligen någon kota av någon strandad val); mer eller mindre planmässigt byggdes universitetsbiblioteken och privata samlingar upp av märkvärdigheter som visade skapelsens mångfald eller dess "essens". Eftersom inte allt kunde visas ville man ge ett representativt urval. Ingen undgick att läsa in åtminstone någon religiös innebörd: se mångfalden, skönheten, Guds fingerfärdighet, naturens sammanhang och symbolvärde! Samlingarna knöts också gärna till de botaniska trädgårdarna, som under 15och 1600-talen utvecklades till universitetens tyngsta utgiftsposter. I dem fanns levande livet, ibland också i form av ett litet menageri. Världen fanns inom räckhåll, till allmän beskådan och förundran.

I Sverige ägde $\mathrm{t}$ ex Olof Rudbeck i Uppsala sådana samlingar. Hans arbetsrum fylldes inte bara av böcker utan av uppstoppade djur, särskilt fåglar från
Lappland, av herbarieark, mineralprover, och av det enorma botaniska planschverket Campus Elysii som han aldrig slutgiltigt lyckades ge ut. Därtill olika uppfinningar, tekniska leksaker, en klocka som visade tiden också om natten, anatomiska preparat, en hjärna hård som sten, blodådror fyllda med kvicksilver, kartor. Åtskilligt, men inte allt förstördes i den stora branden i Uppsala 1702. Det är med hjälp av Johan Eenbergs skildring av katastrofen (1703), som vi kan titta in i det rubeckska kuriosakabinettet.

Vi talar inte om museer i dess moderna betydelse. "Museum" betydde vid den tiden gärna "arbetsrum". "Scribam in Museo mea" - jag har skrivit detta i mitt arbetsrum" - står det ofta som avslutningsfras i de gamla lärdes brev. Så används ordet också i i Comenius Orbis sensualium pictus (1658), den mest spridda av barockens läroböcker och en alltid lika givande encyklopedi över perioden: "Museum est locus ubi studiosus, secretis ab hominibus 
20 solus sedet, studiis deditus, dum lectitat libros." Museet är den plats där studenten sitter ensam, avskild från andra människor, fördjupad i studier medan han läser böcker. Definitionen markerar det privata sanningssökandet, om man så vill den tidiga vetenskapen, och inte museet som en publik inrättning där vem som helst beskåda samlingarna.

\section{NATURALHISTORIEN OCH SAMLANDET}

Det är på 1700-talet, som det naturalhistoriska museet tar form och vars förutsättningar vi följer. Samlandet och ordnandet blev en mani och sitt eget mål. Överallt i Sverige, från kungaparet Adolf Fredrik och Lovisa Ulrika till den enkle lantprästen ägnade man sig åt ett intensivt studium av insekter och örter, vilket Yngve Löwegren visade $\mathrm{i}$ en omfattande inventering. Den religiösa retoriken fanns ofta uttalad men kunde förlora sitt inehåll. Man kan få intrycket att det var samlandet som sådant och inte det insamlade som väckte beundran, alltså det mänskliga insatsen snarare än den gudomliga. Pehr Kalm t ex beskriver i den andan med obegränsad beundran Sir Hans Sloanes samlingar i London (som skulle bli kärnan i British Museum). I motsvarande sekulariserad anda skulle Kalm som den förste vetenskapsmannen beskriva Niagara utan att tala om vad han såg som ett underverk utan i stället fundera över mätteknik och eventuell nytta. Vid mitten av 1700-talet hade på det här sättet föreställningen om en värld av under utmanats av förhoppningen om en värld av nyttor. Naturalhistorien höll på att befria sig från teologin, med förskjutningar i samlandets idé som följd.
Ideolog för den Homo collector sådan vi finner honom (ibland henne) under 1700talet var Carl von Linné. Jag vill påminna om den linneanska vetenskapens kännetecken. Den syftade till en total täckning av naturen, den skulle ordnas hierarkiskt och namnges. Naturen, så såg Linné den, var stabil och förhållandevis harmonisk. Han inspirerades gärna till fysikoteologisk retorik. Gud hade inrättat de tre naturens riken så att det ena stödde det andra, och inom naturrikena längs den linneanska hierarkin (klasser, ordningar, släkten och arter) balanserade det ena det andra. Så uppfattade han livet ut skapelsen som förnuftigt uppbyggd. Men Linné ändrade sig så att disharmoniska inslag gavs mer plats och så att det inom de lägre enheterna pågick förändringar. Den gamle mannen radikaliserades och accepterade faktiskt tanken på att nya arter uppstår. Att allt ytterst vilade på en skapare var från början självklart, men med tiden byttes den individuella skaparhanden ut mot en mer abstrakt skaparplan.

I en sådan förnuftig skapelse gavs inte plats för det oförnuftiga. En av de bedrifter Linné särskilt berömde sig för, var att ha avslöjat "hydran i Hamburg", det månghövdade falsarium sammanställt av olika djurdelar som vunnit åskådare och forskningens tilltro tills den unge svensken på sin utlandsresa enkelt kunde visa att sådana djur bara inte fanns. I de första upplagorna av Systema naturae intogs en avdelning kallad "Paradoxa" eller ickedjur, som svor mot naturens enkla förnuftiga lagar och inte kunde placeras någonstans i systemet. Där fanns grod-fisken, enhörningen, satyren, Barometz eller det skytiska lammet, fågel Fenix osv, en pittoresk blandning hemmahörande i det gam- 
la kuriosakabinettet, men som nu utvisades ur vetenskapen. Inte alldeles entydigt visserligen, Linné hade personligen också en godtrogen sida, men hans inflytande ledde till att ogräset rensades ur åkern.

Hela tiden ny kunskap som rubbade mönstren. Det arbete som skulle samla upp all ny information, Systema naturae, utgavs första gången 1735 och då bara på ett dussin sidor. Den sista upplagan utkom 176668 och omfattade 2300 sidor. Denna iögonfallande ökning innebar påfyllnad men inte så mycket nyorganisation. Som en följd av den linneanska metodens anspråk växte å andra sidan diskussionen av de rent metodiska problemen. Linné var rätt mycket en sparv i denna kunskapsteoretiska tranedans. Själv anknöt han till skolastikens logik medan konkurrenterna insupit Locke och upplysningsfilosofin. Men Linnés system hade hela tiden fördelen att vara användbart, praktiskt och enkelt att lära. Han lappade på sitt bygge och anade dunkla sammanhang som skulle klarna senare.

\section{ENCYKLOPEDI OCH ORDNING}

Sjuttonhundratalets encyklopediska projekt - och museet - stod i nära förhållande till den linneanska naturalhistorien. Historiskt sett delar naturalhistorien och encyklopedismen samma ambition att uppnå totalitet och ordning. I encyklopedins begrepp låg vad ordet bokstavligen betyder, nämligen "kunskapens hela cirkel". Äldre encyklopedier, den mest berömda är kanske Alstedius från barocken men också Ephraim Chambers från 1730-talet, betonade starkt encyklopedins systematiska karaktär. Både naturalhistorikern och encyklopedisten ställde frågan: På vad sätt, med vilken "metod" kan omvärlden ordnas? Finns det verkligen en överensstämmelse mellan vad vi tycker oss skönja och verkligheten som den i själva verket är? Och dessa kunskapsteoretiska problem hörde också till museiväsendets historia från första början.

Linneansk naturalhistoria med dess klara struktur, terminologiska renhet och enkelhet utgjorde en modell för encyklopedisterna men också det kuriösa samlandet, på väg att härmed ömsa skinn till vad vi kallar museum. Vi kan tala om den linneanska encyklopedin och det linneanska museet med rötter i den religiösa tanken om skapelsen som en Naturens Bok med olika kapitel och versar begripliga för den rätt läskunnige naturalhistorikern. Och att läsa är att behärska. Den mer eller mindre medvetna avsikten som var att ta det upptäckta och erövrade i besittning, kännetecknar både Systema naturae och den stora franska encyklopedin. Det är ingen tillfällighet att d'Alemberts och Diderots stora arbete började utkomma samma år som Buffons encyklopediska Histoire naturelle och den franska geodetiska mätningen påbörjades.

Men dessa "projekt" bar vart och ett på problem som skulle leda till deras upplösning. Den franska encyklopedin var ett samarbete mellan en rad medarbetare som aldrig riktigt kunde enas. Systema naturae, ett enmansjobb, syftade till en indelning baserad på "naturliga" principer, för växterna deras sexualitet. För Linné var det självklart att deras könsorgan var viktigare än andra organ eftersom de uppfyllde själva skapelsens mening att föröka sig.

För andra var detta bara gammal skolastisk "essentialism". Den franska Encyklopedin förnekade varje djupare försök att skapa en ordning. Visserligen talar d'Alem- 
22 bert åtskilligt i förordet om systematisk kunskap och visserligen ingår den ståtliga planschen över kunskapernas sammanhang och klassificering i form av ett träd, men själva texten lyder bara alfabetets ordning. Den är helt tillfällig medan Linné söker en evig indelning enligt "naturen" eller i överensstämmelse med skapelsen. I Encyklopedin får biet en annan plats vid översättning till tyska, men i Systema naturae behåller det sin placering oavsett språk och - så var förhoppningen - oavsett tid.

Ordning hänger också samman med antal. "Tot numeramus quot in initio Deus creavit" - vi räknar i dag lika många arter som Gud skapade i begynnelsen skriver Linné i en fundamentalsats i Systema naturae. Något helt annat skriver Diderot i artikeln "Encyclopedie" (1755) i den stora franska encyklopedien: "Universum uppvisar för oss blott enskilda ting, oändliga till antalet och med nästan ingen klar eller bestämd delning mellan sig. Inget av dem kan kallas den första eller den sista; allt är förbundet med allt annat genom omärkliga grader." Avslutningen anknyter till den populära föreställningen om naturens stora kedja.

Diderot insisterar på värdet i det oregelbundna: "Formeringen av en encyklopedi liknar byggandet av en stor stad." Han jämför encyklopedisk ordning med en maskin, delarna passar ihop men kan också byggas ihop på ett helt nytt sätt. Snarare än att utgöra en organiserad helhet av all mänsklig kunskap borde Encyklopedin med sina korsreferenser utgöra en "öppen konversation mellan medlemmarna i vetenskapssamhället". Ett samtal - så olinneanskt! Skaparguden hade ingen att prata med. Om vi ska ställa dem emot varandra så förordar Diderot, som inte ska uppfattas som typisk för någon mer än sig själv, en dynamisk naturuppfattning, medan Linné förespråkar en stabil.

Betydelsen av Encyklopedins alfabetiska uppställning kan lätt förbises, men som en fransk forskare uttryckt det: "Som taxonomins nollgrad tillåter alfabetisk ordning alla sätt att läsa; i så måtto kan den uppfattas som Upplysningens emblem." (Charles Porset) Man syftade till information och inte kunskap eller bildning. Den gamla encyklopedins dagar var över, också Encyclopedia brittanica (1768) följde en alfabetisk uppställning. I början av nästa århundrade kom det populära Konversationslexikonet, Brockhausfirmans lyckokast. Men akademiker fnyste åt nymodigheterna, de ville ha ordning och system.

\section{NATURENS GRÄNSLÖSHET}

Besläktat med ordningens problem finns frågan om naturens omfång. Vi kan börja med John Ray. Den viktige engelske naturalhistorikern inleder sitt mycket spridda arbete The wisdom of God manifested in the world of creation (1691) med att citera Psaltaren: "How manifold are not thy works, O Lord!" Utropet ändrar han sedan till en fråga: Hur stort är egentligen artantalet i världen? Ray beräknar att det måste finnas 2.000 insektarter bara i England och kanske 20.000 i världen, säkert höga siffror för den tiden liksom den totala summan för både växter och djur, runt 40 - 45.000. Han diskuterar också förhållandet mellan artantal och naturbalans. Vi kan notera en tidstypisk turnering: ju fler varianter, desto större ära för människan för vilken allt detta skapats av den gode Guden. 
Som en följd av nyupptäckt material och utfört taxonomiskt arbete blev beräkningarna allt högre. Men Linné själv höll sig till ganska måttliga antal och klassificerade inte fler än ca 15.000 arter. Men ju mer han arbetade desto tydligare framstod det att han aldrig skulle kunna slutföra sin uppgift. Författarexemplaret av Systema naturae är fyllt med tillägg. Indirekt resonerade Linné om hur mycket som egentligen kunde rymmas i den struktur han givit naturbeskrivningen (ämnet är komplicerat och lämnas här) och uppenbarligen kunde han tänka sig en natur av helt annat omfång. Han måste vidare allt mer inse att han visserligen gav ett system över naturen men att det för den skull inte var "naturligt". Strukturerna var oklara, symmetrin i gungning redan för Linné. Naturen var inte längre ett skåp försett med ett antal utdragbara lådor eller ett regelbundet och överskådligt kabinett. För varje dag som gick föreföll det allt mer komplicerat och mångfaldigt. När Linné börjat sitt värv var världen relativt liten, mot slutet av sitt liv måste han ha anat att den är outtömlig.

Det mest ambitiösa försöket under 1700-talet att få siffror på naturens innehåll gjordes av Eberhard Zimmermann i hans bok Geographische Geschichte des Menschen und der allgemein vierfüssigen Thieren (1778-83). Zimmermann som bl a varit lärare till matematiksnillet Gauss excellerar i olika kalkyler av den kända och okända världen. Han uppskattar antalet växtarter till ca 175.000 och eftersom var och en av kan hysa ca 5 insekter så skulle antalet entomologiska arter ligga runt 875.000 - av vilka blott ca 50.000 beskrivits. Naturen vimlar av insekter, haven är tjocka av liv. Troligen är variatio- nen av havsorganismer tre gånger större än landdjur, sålunda ca tre millioner. Zimmermann pekar på den flödande mångfald av liv mikroskopet visar. Plötsligt har jordens artantal stigit till ca fyra miljoner - från Linnés 15.000. Och varför skulle inte också planeterna hysa levande väsenden. Varför, menade Zimmermann på gott 1700-talsmanér, skulle den gode guden annars ha skapat himlakropparna.

Denna materialökning var en följd av resenärernas hemsläpade fynd, av artjägarnas goda skörd, men också av föreställningen av naturens som en "plenitudo" eller "idén om fullhet". Denna allgivande natur kunde uppfattas sekulariserat men också som belägg för Guds generösa skaparhand och oändliga skicklighet. Varje vattendroppe, varje liten jordhög myllrade av liv. Naturen, skapad eller ej, var definitionsmässigt outtömlig.

Enda sättet att få plats för naturens mångfald och mångsidighet var att använda matematik. Den linneanske naturalhistorikern räknade ståndare och pistiller, tänder och bröstvårtor, naglar, klor, antenner osv. Metoden visade här sin effektivitet. Till fördelarna hörde matematisk korthet och exakthet. Linné, som i flera bemärkelse var en ekonomisk person, visste hur boksidan bättre räcker till med hjälp av viss formalisering. Utan den linneanska vetenskapen skulle det varit omöjligt att göra en överblick av naturen, med den kunde naturen framstå som abstrakt och artificiell, som en enda lång lista av siffror.

En framställning av det här slaget ifrågasattes av Buffon, Linnés franske motpol. I en inledning till sin mäktiga Histoire naturelle (1749) hävdade Buffon att arten lik- 
24 som högre enheter $\mathrm{i}$ den linneanska hierarkin blott var mänskliga konstruktioner. Naturen består inte av sådant utan av enskilda individer. Hela naturen är ett enda kontinuum och det enda sättet att förstå naturen, den enda rimliga "metoden", är att utgå från subjektets upplevelse och att ordna beskrivningarna därefter. Väsentligt är vidare att använda vanliga ord, språket och dess uttrycksmedel. I Buffons händer tenderar naturalhistorien så när att bli till ordrik litteratur och inte strikt vetenskap.

Den filosofiska kärnan i Buffons och andras (entomologen Réaumur, botanisten Adanson osv) invändningar var tanken om "naturens stora kedja" och naturens kontinuitet. I sin monografi över temat framhåller A.O. Lovejoy artproblemet, sökandet efter felande länkar, mikroskopisternas studier av mikroliv som uttryck för samma tankefigur. Kedjemodellen förutsatte kontinuitet och även föreställningen om "fullhet", men om det är så blir varje gränsdragning besvärlig. Om det finns kontinuitet längs hela skalan så borde samma klassifikatoriska kriterier kunna användas hela vägen. Linné kunde bara med svårighet utsträcka sitt sexualsystem genom växtriket - fortplantingsorganen hos kryptogamerna iakttogs aldrig utan förutsattes bara. Mellan en art och en annan måste det finnas otaliga individer av osäker ontologisk position och stor tveksamhet inför artbegreppet. Resonemang av det här slaget kunde leda till ett sorts taxonomiskt självmord.

Om naturen visar kontinuitet måste den innehålla en mängd "affiniteter", ett nyckelord i det sena 1700-talets naturspekulation. Det kunde betyda "närhet" i allmänhet på kedjan men också inbegripa någon sorts genetisk släktskap. En tysk zoolog (Johan Hermann) kunde genom att arbeta med tio variabler beräkna att det mellan två skalbaggsarter kunde finnas 10.172.640 möjliga varieteter. Men var går då gränserna? Kan man tänka sig så många arter? Och kan vi, med anspråk på fullständighet, tänka oss en sammanhängande serie av museiföremål, osagt om de hör hemma i naturen eller kulturen?

Låt mig summera. Vi kan se två skilda teman som leder till samma slutsats: den gamla idén om encyklopedisk ordning och totalitet hade visat sig omöjlig att förverkliga; enkel alfabetism fick ersätta. Och tanken om naturen som en kedja, en plenitudo, framfördes som en "sannare" naturalhistoria; naturen var alltför svår för att förstå av en man och ett århundrade, Linnés metod var orimligt optimistisk. Kritiken kunde förstås inte annat än medge att den å andra sidan var enkel och praktiskt fungerande. Den linneanska metoden gick på kryckor, men det linneanska projektet var en succé.

\section{DET VETENSKAPLIGA MUSEET}

Många både professionella och amatörer lockades till naturalhistorien. Fler och fler arbetade med namngivande och ordnande av den levande världen. Linnés metod vann över rivalernas och spred sig till angränsande områden. På samma sätt som fysiken hade varit en idealvetenskap efter Newton blev naturalhistorien i Linnés form det under 1700-talets andra hälft. Ett gemensamt internationellt språk utvecklades, med fast terminologi och namngivning. Ännu idag är de binära namn Linné gav till växter och djur giltiga och namngivningsmetoden används fortfarande. Den veten- 
skapliga internationalismen befrämjades genom handel med frön och torkade växter och djur liksom resande naturalhistoriker. De linneanska apostlarna, de antropologiska huvudjägarna, kapten Cooks ressällskap, upptäcktsresenärer, artister, samlare, alla förde de med sig hem en rik skörd från fältet. Det linneanska projektet utgjorde - med ett ord som brukar användas för senare perioder - "big science". I Sverige blev det en nationalvetenskap.

Som ett led i en ny estetik och en ny uppskattning av naturen intresserades också allmänheten av naturalhistorien. (Detta är åtminstone vad som något schablonartat brukar sägas av idéhistoriker.) Naturalhistoriens institutionella styrka framgår av hur akademiska trädgårdar och museer växte. Den svenska vetenskapsakademin hade från sin start 1739 samlingar, men de var inledningsvis av ganska säreget slag, ett sjörås tumme och diverse exotica. Fram mot slutet av århundradet hade flera större donationer inkorporerats varför man också höll sig med en intendent. (Föga framgångsrik på posten var Anders Sparrman, jorden-runtresenären med kapten Cook.) Besök vid berömda institutioner av det slaget var varje resenärs plikt. Museerna, nu inte längre kuriosakabinett utan institutioner i vetenskapens tjänst, var på väg in i en ny epok. I Frankrike, där mottagandet av Linnés läror till en början varit kyligt, omorganiserades efter revolutionen Jardin du Roi efter en modifierad linneansk plan.

Snarare än att visa upp hela den gudomliga ordningen så kunde samlaren eller museet ägna sig åt att vara mer komplett än sin kollega. Tävlingsmomentet i samlandet blev allt mer tydligt, men det var ett lopp utan fixerad mållinje. När Carl Peter Thunberg, Linnés efterträdare och 250-årsjubilar i år, fick sitt Botanicum byggt runt 1800 , gavs av arkitekten (Tempelman) bara plats för ett herbarium om ca 15.000 exemplar. Snart nog fylldes varje skrymsle i den vackra hallen, ett uttryck för Thunbergs och hans efterträdares framgångsrika flit. I skrift gav han ut en oändlig serie dissertationer över de akademiska samlingarna, som vittnade om oavbruten ackumulation som aldrig ändå blev färdig (Museum naturalium academiae upsaliensis, 29 delar). Thunbergs samtida, entomologen och swedenborgaren Schönherr skrev sexton volymer om sammanlagt 5000 sidor enbart om skalbaggsgruppen curcurlionides eller vivlar. Drömmen om fullständighet fortlevde bara som en drömmen om fullständighet inom ett delområde. Man registrerade fakta, men hur de hängde ihop var en fråga som bara framtiden - eventuellt - kunde lösa.

Ingen kunde längre behärska hela naturalhistorien. Utvecklingen gick mot specialisering. Situationen ledde också till en specialiserad bokutgivning med nya handböcker för ornitologer, entomologer och mykologer, tidskrifter och monografier. En ny genre, det naturalhistoriska lexikonet, uppstod. Alfabetiskt uppställt efterliknade det de nya encyklopedierna och konversationslexika. "Fakta" skulle tala för sig själva och vara snabbt och överskådligt tillgängliga. De stora sammanhangen var mindre viktiga eftersom de ändå inte kunde visas hållbara. Men information, snabb och föränderlig, ville man ha.

Min beskrivning ger bara en förgrovad bild av vad som skedde under lång tid och som fortfarande sker. För sjuttonhundratalets samlande hänvisas till Löwegrens detaljspäckade avhandling; utvecklingen under artonhundratalet kan bara snuddas vid. Men tendensen till förändring fanns 
GUNNAR BROBERG

26 alltså tidigt. Naturalhistorien gick mot det abstrakta, den hamnade i bryderi i förhållande till de kunskapsteoretiska frågorna och den höll på att gå under inför mängden av material; den linneanska eran hade verkligen vidgat gränserna för natursstudiet. Men det naturalhistoriska museets överlevnadsförmåga har alltså visat sig vara stark.

Allt detta måste ha påverkat museernas egenliv, om det finns ett sådant. Uppgiftens storlek innebar att en professionell museikår (föreståndare, taxidermister, vaktmästare osv) uppstod. Uppgiften krävde också utrymme. Mot slutet av 1800-talet byggs i nationalistisk anda enorma tempel till naturalhistoriens ära, t ex 1882 British Museum (Natural History) i Kensington med en längd om 209 meter och höjd om 52 meter. Riksmuseet i Stock-holm (1915) är Sveriges största offentliga byggnad, men har likafullt problem med att bereda plats åt de svällande samlingarna. På samma sätt som de taxonomiska översiktsverken tvingats till supplement byggde museerna med tiden sina annex.

Utvecklingen ledde också till att museet splittrades i två syften. Det ena med utgångspunkt i Comenius' definition betonade museet som en studieplats, arbetsrum och forskningshärd. De vetenskapliga museerna - British Museum, Riksmuseet slöt sig också inom sig själva. I denna dolda värld samlade man i stället typexemplar, de individer som så att säga utgjorde artens urbild i Platons mening. Och Platon måste uppfattas som det synligas och taktilas ärkefiende. Till det vetenskapliga museet ägde inte kreti och pleti tillträde.

Det andra underströk museets publika och undervisande roll. Liksom i kuriosakammaren skulle man förundras där, över vad som var sällsyntast, störst, minst och äldst. Magnitud och minitud är alltid intressant. Länge var valavdelningen museets bästa attraktion. Kolibris finns exponerade i varje museum med självaktning. Pedagogiken var effektiv. I American Museum of Natural History lika väl som i Riksmuseet i Stockholm ställdes de stora aporna ut $\mathrm{i}$ våldsamma positioner. Besökaren bevittnade en värld av våld och kamp. Som kontrast och uttryck för det trygga familjeidealet fanns i Stockholm en monterad myskoxfamilj till beskådan. Museet lär ut samhällets värderingar lika mycket som naturen i sig - om något sådant finns.

Man kan med Max Weber tala om en naturens "avförtrollning" (Entzauberung), påbörjad av den linneanska namnreformen (som inte berörts här, men som innebar att gamla lokala, gärna beskrivande benämningar ersattes av internationella latinska formella namn) och den abstrakta linneanska klassificeringen. Och denna moderna naturalhistoria växte fram i samspel med museiväsendet, som vände sig utåt och inåt, fram till dagens upplevelsemuseer i kontrast till och konflikt med det biologiska arkivmuseet.

Naturalhistorien hörde $\mathrm{i}$ under sin förhistoria samman med kuriosakabinettens mikrokosmtanke. När denna sedan splittrades utgjorde naturens kedja en ordnande princip. Den i sin tur avlöstes av darwinismens historieperspektiv, som med härkomsten som grundperspektiv förmådde locka den stora publiken. Vår plats i skapelsen blev på nytt ett tema för utställandet. Kolonialismens och imperialismens skördar fyllde museerna med löften om äventyr och bättre villkor. Idag är naturens mångfald stapelvara i magasinen samtidigt som naturen i miljökrisens dagar håller på 
att ta slut. Museet blir antingen trist upprepning, dyster slutrapport eller barnslig lek.

Men fortfarande försöker vi framställa världen så att den är full av under. Men "under" i förhållande till vad? Vi måste till en annan värld för att förundras. När på biograferna Yurassic parks dinosaurier rullar upp är det på nytt en undrens värld som beskådas. Men det är tekniken made in Hollywood som vi ägnar vår förundran. Naturen är underhållning, skapad av oss människor.

\section{SUMMARY}

$A$ wondrous world.

The idea of the natural history museum is traced back to the cabinet of curiosities and connected to the development of Linnean taxonomy. Two problems are singled out as decisive in the shape of the modern natural museum: taxonomic epistemology (how to find the right characters in arranging plants and animals) and the problem of continuity and multitude in nature. The result, obvious at least at the end of the 18th century, is a division of the natural history museum into two types: one the museum in the meaning of Comenius, i. e. for study and scholarship, the other the museum made public and educational in the manner of the cabinet of the curiosities. The argument of this brief essay is more fully developed and put in connection with the history of the encyclopedia in the essay by Broberg, "The broken circle".

Gunnar Broberg, professor i idé- och lärdomshistoria vid Lunds universitet, har forskat om Linné och om rashygienens historia; 1992 utgav han den idéhistoriska tvåbandsantologin Gyllene äpplen.

Adr: Institutionen för idéhistoria, Lunds universitet, Kungshuset, Lundagård, S-22350 Lund. Fax +46-46 104424
LITTERATUR

Broberg, Gunnar, "The broken circle", The quantifying spirit, ed Frängsmyr T. et al. Berkeley 1989.

Broberg, Gunnar "The Swedish Museum of Natural History", Science in Sweden, ed Tore Frängsmyr. Uppsala 1989.

Lovejoy, Arthur O., The great chain of being. Cambrigde Mass $1936 \mathrm{~m}$ fl uppl.

Löwegren, Yngve, Naturaliekabinett i Sverige under 1700-talet. Uppsala 1952.

Porset, Charles, "Figures de l'encyclopedie", Le siècle de Voltaire. Hommage à René Pomeau. Oxford 1987.

Thomas, Keith, Människan och naturen. Stockholm 1988.

Tvärsnitt 1991:2-3 olika artiklar bl a Sverker Sörlin och Gunnar Broberg 